\title{
LA MINERÍA SOCIAL COMO ALTERNATIVA DE GESTIÓN COLECTIVA DE RECURSOS EN LA PROPIEDAD SOCIAL
}

\section{SOCIAL MINING AS AN ALTERNATIVE OF COLLECTIVE RESOURCE MANAGEMENT IN SOCIAL PROPERTY}

\author{
Ignacio Morales-Lormendez, Hermilio Navarro-Garza*, Diego Flores-Sánchez \\ Posgrado PSEI-Desarrollo Rural, Colegio de Postgraduados (morales.ignacio@colpos.mx; \\ hermnava@colpos.mx; dfs@colpos.mx)
}

\begin{abstract}
RESUMEN
La minería social se considera una opción histórica para el desarrollo local, frente a la modalidad dominante de la minería comercial de interés de grandes empresas internacionales y nacionales, misma que ha desposeído recientemente de millones de ha a los propietarios originales. La minería social es un tipo de pequeña y mediana minería donde participan ejidos y comunidades agrarias, dedicadas principalmente al aprovechamiento y valoración de minerales no metálicos, contemplada como opción y oportunidad para el desarrollo económico, organizacional y social. Se utilizaron entrevistas semiestructuradas y cuestionarios para identificar los procesos y situación organizativa de la comunidad, recabar datos sobre producción, costos e ingresos por la venta de mármol. Se encontró que la comunidad agraria ha generado su propia estructura organizativa, y modalidades normativas que regulan el acceso al recurso; las características de las organizaciones de productores determinan la capacidad de su sistema relacional para comercialización, obtención de créditos, transacciones con compradores y gestión de procesos institucionales. Es necesario consolidar la organización comunitaria y la integración de las cooperativas productoras de mármol para incursionar en encadenamientos de valor agregado.
\end{abstract}

Palabras clave: autogestión, cooperativas, mármol, organización, Otomí (ñhöñhö).

\section{INTRODUCCIÓN}

L as zonas rurales son importantes reservorios de recursos naturales bióticos y abióticos que pueden generar tanto ingresos económicos para los pobladores de estas áreas, como servicios ecosistémicos,

* Autor responsable $*$ Author for correspondence.

Recibido: noviembre, 2016. Aprobado: julio, 2018.

Publicado como ARTíCULO en ASyD 18: 25-47. 2021.
ABSTRACT

Social mining is considered a historical option for local development, facing the dominant modality of commercial mining of interest to large international and national companies, which has recently dispossessed the original owners of millions of ha. Social mining is a small and medium scale type of mining where ejidos and agrarian communities participate, devoted primarily to the exploitation and valuation of nonmetallic minerals, contemplated as an option and opportunity for economic, organizational and social development. Semistructured interviews and questionnaires were used to identify the processes and organizational situation of the community, and to gather data about production, costs and income from marble sales. It was found that the agrarian community has generated its own organizational structure and normative modalities that regulate access to the resource; the characteristics of producers' organizations determine the ability of a relational system for trade, obtaining credits, transactions with buyers and management of institutional processes. It is necessary to consolidate the community organization and the integration of marble producing cooperatives to make an incursion into added value chains.

Key words: self-management, cooperatives, marble, organization, Otomí (ñhöñhö).

\section{INTRODUCTION}

$\mathrm{R}$ ural zones are important reservoirs of natural biotic and abiotic resources that can generate both economic income for inhabitants of these areas and ecosystem services, defined as the benefits that people obtain from ecosystems (MEA, 2005). Inside these zones there are ejidos and agrarian communities that hold the social property in the country which have created, accumulated and 
definidos como los beneficios que las personas obtienen de los ecosistemas (MEA, 2005). Dentro de estas zonas se encuentran los ejidos y comunidades agrarias que ostentan la propiedad social del país; las cuales han creado, acumulado y recreado un conjunto de recursos cognitivos y prácticas diversas con fines de la utilización sociotécnica de sus recursos. En México existen 32076 núcleos agrarios, de los cuales 29683 son ejidos y 2393 son comunidades agrarias, que poseen una superficie de 99961097.25 hectáreas que están bajo el régimen de propiedad social (RAN, 2016a). Más de la mitad del territorio continental nacional está bajo el régimen de la propiedad social. De ahí la importancia de profundizar en las dinámicas del manejo de recursos emprendidos por los núcleos agrarios poseedores originales.

Las comunidades rurales son núcleos agrarios con personalidad jurídica y patrimonio propio, constituido por tierras, bosques y aguas, cuyo reconocimiento deriva de una resolución presidencial de restitución o confirmación o por conversión. Los órganos de la comunidad son la Asamblea de Comuneros como órgano supremo y el Comisariado de Bienes Comunales como representante del núcleo de población y administrador de los bienes comunales en los términos que fije la Asamblea (Cámara de diputados, 2012).

Los sistemas organizativos existentes en los espacios rurales están basados en el manejo de recursos escasos y vitales para la supervivencia de campesinos e indígenas y comprenden una estrategia de vida basada en buena medida en el manejo colectivo de los recursos, trátese de sistemas de riego, pastizales o bosques (Davison, 2007). El alto nivel organizativo de algunos grupos rurales se basa en la importancia que le dan a la red de beneficios materiales que obtienen de tal organización por todos o la mayoría de los participantes, aunque en algunos estudios se reconoce un mal manejo de algunos recursos, muchos otros casos plantean realidades que ejemplifican el cómo estas formas de organización colectiva pueden ser eficientes (Wade, 1994).

El manejo de recursos colectivos ha sido ampliamente estudiado por diversos autores, y han ofrecido diferentes perspectivas para su estudio, características y naturalezas. Así, Helfrich (2008) señala que el concepto de bienes comunes, más allá de la terminología concreta en distintos artículos, da sentido y dirección a una propuesta política, y trata cuatro temas esenciales: (1) el control sobre el uso y manejo de recursos recreated a set of cognitive resources and various practices with the aim of sociotechnical utilization of their resources. In Mexico there are 32076 agrarian nuclei, of which 29683 are ejidos and 2,393 are agrarian communities, which have a surface of 99961097.25 hectares that are under the social property regime (RAN, 2016a). More than half of the national continental territory is under the social property regime; thus the importance of delving into the dynamics of resource management undertaken by the agrarian nuclei that are original owners.

Rural communities are agrarian nuclei with legal entity and patrimony of their own, constituted by lands, forests and water, whose recognition derives from a presidential resolution of restitution or confirmation or from conversion. The authorities in the community are the Comunero Assembly as supreme organization and the Communal Goods Commissary as representative of the population nuclei and administrator of communal goods in the terms that the Assembly establishes (Cámara de diputados, 2012).

The existing organizational systems in rural spaces are based on the management of scarce and vital resources for the survival of peasants and indigenous people, and they comprise a life strategy based largely in the collective management of resources, whether irrigation systems, grasslands or forests (Davison, 2007). The high organizational level of some rural groups is based on the importance given by all or most of the participants to the network of material benefits that they obtain from such an organization; although in some studies an ill management of some resources is recognized, many other cases suggest realities that exemplify how these forms of collective organization can be efficient (Wade, 1994).

The management of collective resources has been widely studied by various authors, and they have offered different perspectives for their study, characteristics and natures. Thus, Helfrich (2008) points out that the concept of common goods, beyond the concrete terminology in different articles, gives sense and direction to a political proposal and deals with four essential themes: (1) control over the use and management of resources and goods that make up our social, natural and cultural patrimony; (2) access to these resources and goods; (3) process of social production and reproduction both of goods and of the commonwealth; and (4) distributive 
y bienes que conforman nuestro patrimonio social, natural y cultural; (2) el acceso a dichos recursos y bienes; (3) el proceso de producción y reproducción social tanto de bienes como del bien común (Commonwealth); y (4) la justicia distributiva en la repartición de los beneficios que emergen de nuestro acervo común.

De acuerdo con Feeny et al. (1990) los recursos de propiedad común comparten dos importantes características. La primera es exclusividad (o control del acceso), es decir, la naturaleza física del recurso es tal que el control del acceso a usuarios potenciales puede ser costoso y, en el extremo, virtualmente imposible; la segunda característica básica de los recursos de propiedad común es la sustractabilidad, esto es, cada usuario es capaz de sustraer o usar del bien de otros usuarios, la naturaleza del recurso es tal que el nivel de explotación hecho por un usuario afecta adversamente la capacidad de otro usuario de explotar el recurso, incluso si los usuarios trabajan para mejorar la productividad de su recurso, por ejemplo replantando árboles. Para este autor, la sustractabilidad (o rivalidad) es la fuente de divergencia potencial entre racionalidad individual y colectiva.

Feeny et al. (1990) señalan que en la propiedad comunal, el recurso pertenece a una comunidad identificable o usuarios interdependientes, estos usuarios excluyen a los foráneos mientras regulan el uso para los miembros de la comunidad local. El mismo autor afirma que en la comunidad, es improbable que los derechos al recurso sean exclusivos o transferibles; generalmente son derechos de igualdad en el acceso y el uso.

La minería es el conjunto de actividades y labores para descubrir y extraer físicamente los minerales de la corteza terrestre en forma de rocas, de metales o no metales (CIDVT, 2016). Existen diferentes tipos de minería, en México el reglamento de la ley minera menciona la gran minería, establece criterios de clasificación de la pequeńa y mediana minería, y menciona el sector social en la minería (Cámara Diputados, 2014).

La minería social es un tipo de pequeña y mediana minería en el que participan ejidos y comunidades agrarias, es un importante detonador del desarrollo económico en las zonas rurales, permite complementar el ingreso de las familias campesinas, fomenta la generación de fuentes de empleo permanente y por ende el arraigo de los campesinos a sus lugares de justice in the share-out of the benefits that emerge from our common heritage.

According to Feeny et al. (1990), the resources of common property share two important characteristics. The first is exclusivity (or access control), that is, the physical nature of the resource is such that access control to potential users can be costly and, in the extreme, virtually impossible; the second basic characteristic of the common property resources is subtractability, that is, that each user is capable of subtracting or using the good from other users, the nature of the resource is such that the level of exploitation made by one user affects adversely the ability of another user to exploit the resource, even when users work to improve the productivity of their resource, for example replanting trees. For this author, subtractability (or rivalry) is the source of potential divergence between individual and collective rationality.

Feeny et al. (1990) point out that in communal property, the resource belongs to an identifiable community or interdependent users, these users exclude outsiders while they regulate the use for members of the local community. The same author states that in the community, it is unlikely that the rights to the resource are exclusive or transferable; these are generally equality rights in the access and the use.

Mining is the set of activities and tasks to discover and physically extract the minerals from the Earth's crust in form of rocks, metals or non-metals (CIDVT, 2016). There are different types of mining, in Mexico the regulations of the mining law mention large-scale mining and establish classification criteria of small and medium scale mining, and they mention the social sector in mining (Cámara Diputados, 2014).

Social mining is a type of small and medium scale mining in which ejidos and agrarian communities participate; it is an important detonator of economic development in rural zones, it allows complementing the income of peasant families, promotes the generation of permanent sources of employment, and therefore the rootedness of peasants to their places of origin under better living conditions (SAGARPA, 2000; FONAES, 1998). The ejidos and communities that practice social mining can carry out the exploitation of minerals of all types. ITAM (2004) points out that this type of mining is characterized by being directed primarily to exploitation, processing 
rigen en mejores condiciones de vida (SAGARPA, 2000; FONAES, 1998). Los ejidos y comunidades practicantes de la minería social pueden realizar el aprovechamiento de minerales de todo tipo. ITAM (2004) señala que este tipo de minería se caracteriza por estar dirigida principalmente a la explotación, beneficio o comercialización de minerales no metálicos, sobre todo rocas dimensionables (mármol, granito, cantera, ónix) porque se trata de minerales no concesibles (exentas del pago de derechos y obligaciones mineras). SAGARPA (2015) la considera como realizada por personas físicas y morales dedicadas a la explotación de minerales no metalíferos y rocas. La Dirección General de Minas (2012) señala que el mármol, como todas las rocas dimensionables, no está incluida en la Ley Minera como concesionable; su extracción está exenta de pago por derechos mineros a nivel federal y es propiedad del dueño del terreno siempre que su extracción sea por tajo o en cantera. Se registra que las principales regiones productoras en México se localizan a lo largo de la vertiente norte del eje volcánico, la enorme extensión territorial que abarca esa área, refleja el alto potencial productivo de México. En el estado de Querétaro existen zonas productoras de relevancia. Los objetivos de la presente investigación fueron: a) identificar y caracterizar los procesos organizativos y formas asociativas para la apropiación del mármol como recurso colectivo de la comunidad agraria de Sombrerete; b) caracterizarlas modalidades de producción y comercialización, con la finalidad de conocer su influencia en la economía, bienestar local y alternativas para su desarrollo.

\section{Región de estudio}

El estado de Querétaro cuenta con 356 ejidos y 16 comunidades, de las cuales 13 comunidades se encuentran en el municipio de Cadereyta de Montes, una de ellas es la comunidad de estudio de Sombrerete.

La comunidad agraria de Sombrerete, se encuentra en la microrregión indígena-otomí del mismo nombre, está integrada por cuatro localidades: Sombrerete, La Laja, El Membrillo y El Soyatal (Cuadro 1). Su origen se remonta a la fundación de la Villa de Cadereyta en 1640, la cual se realizó por españoles con una importante población indígena otomí proveniente de la provincia de Xilotepec (Mendoza et al., 2006). or trading of non-metallic minerals, particularly dimensionable rocks (marble, granite, quarry, onyx) because there are non-concessible minerals (exempt from payment of rights and mining obligations). SAGARPA (2015) considers it as performed by natural and moral persons devoted to the exploitation of non-metal minerals and rocks. The General Mines Direction (2012) points out that marble, as all the dimensionable rocks, is not included in the Mining Law as concessible; their extraction is exempt from payment of mining rights at the federal level and it is property of the land owner as long as their extraction is by work site or quarry. The main producing regions in Mexico are found to be located along the northern gradient of the volcanic belt, and the huge territorial extension that covers this area reflects the high productive potential of Mexico. In the state of Querétaro there are important producing zones. The objectives of this study were: a) to identify and characterize the organizational processes and associative forms for the appropriation of marble as collective resources of the agrarian community of Sombrerete; b) to characterize modalities of production and commercialization, with the aim of understanding their influence on the economy, local welfare and alternatives for their development.

\section{Study region}

The state of Querétaro has 356 ejidos and 16 communities, of which 13 communities are found in the municipality of Cadereyta de Montes; one of them is the community of study of Sombrerete.

The agrarian community of Sombrerete is located in the indigenous Otomí micro-region by the same name, and it is made up of four localities: Sombrerete, La Laja, El Membrillo and El Soyatal (Table 1). Its origin dates back to the foundation of Villa de Cadereyta in 1640, which was carried out by the Spanish with an important indigenous Otomí population from the province of Xilotepec (Mendoza et al., 2006).

The municipality of Cadereyta de Montes is located in the eastern part of the state of Querétaro, between parallels $20^{\circ} 34^{\prime}$ and $21^{\circ} 01^{\prime}$ of latitude North; between meridians $99^{\circ} 23^{\prime}$ and $99^{\circ} 52^{\prime}$ of longitude West; altitude between 800 and 3200 masl (INEGI, 2010a). The agrarian community of Sombrerete is located in the eastern zone of the municipality (Figure 1). The climates are semi- 
Cuadro 1. Localidades y datos poblacionales de la comunidad agraria Sombrerete.

Table 1. Localities and population data from the agrarian community of Sombrerete.

\begin{tabular}{lccccc}
\hline $\begin{array}{c}\text { Nombre de la } \\
\text { localidad }\end{array}$ & $\begin{array}{c}\text { Altitud } \\
(\mathrm{msnm})\end{array}$ & $\begin{array}{c}\text { Población } \\
\text { total }\end{array}$ & $\begin{array}{c}\text { Población económicamente } \\
\text { activa }\end{array}$ & $\begin{array}{c}\text { Población } \\
\text { ocupada }\end{array}$ & $\begin{array}{c}\text { Grado de } \\
\text { marginación }\end{array}$ \\
\hline Sombrerete & 2539 & 594 & 169 & 164 & 157 \\
La Laja & 2548 & 463 & 160 & 80 & Alto \\
El Soyatal & 2439 & 248 & 86 & 103 & Alto \\
El Membrillo & 2455 & 282 & 522 & 504 & Alto \\
\hline Total & & 1587 & & 504 \\
\hline
\end{tabular}

Fuente: INEGI, 2010b y CONAPO, 2012. Source: INEGI, 2010b and CONAPO, 2012.

El municipio de Cadereyta de Montes se localiza al este del estado de Queretaro, entre los paralelos $20^{\circ} 34^{\prime}$ y $21^{\circ} 01^{\prime}$ de latitud norte; los meridianos $99^{\circ} 23^{\prime}$ y $99^{\circ}$ $52^{\prime}$ de longitud oeste; altitud entre 800 y 3200 msnm (INEGI, 2010a). La comunidad agraria de Sombrerete se localiza en la zona este del municipio (Figura 1). Los climas son semiseco templado en la parte baja asociado a vegetación de matorral y templado subhúmedo con lluvias en verano en la parte alta, asociado a bosque de pino-encino (INEGI, 2015).

De acuerdo con el Cuadro 1 la población total suma 1587 habitantes, al interior de la cual dry temperate in the low part associated to shrub vegetation, and sub-humid temperate with summer rains in the high part, associated to pine-oak forest (INEGI, 2015).

According to Table 1 the total population is 1,587 inhabitants, inside of which the economically active population registered as occupied makes a total of 504. The total is a reference regarding the occupied population in community mining. According to INEGI (1991), noticeably $23 \%$ of the population of the agrarian community of Sombrerete cannot read or write.

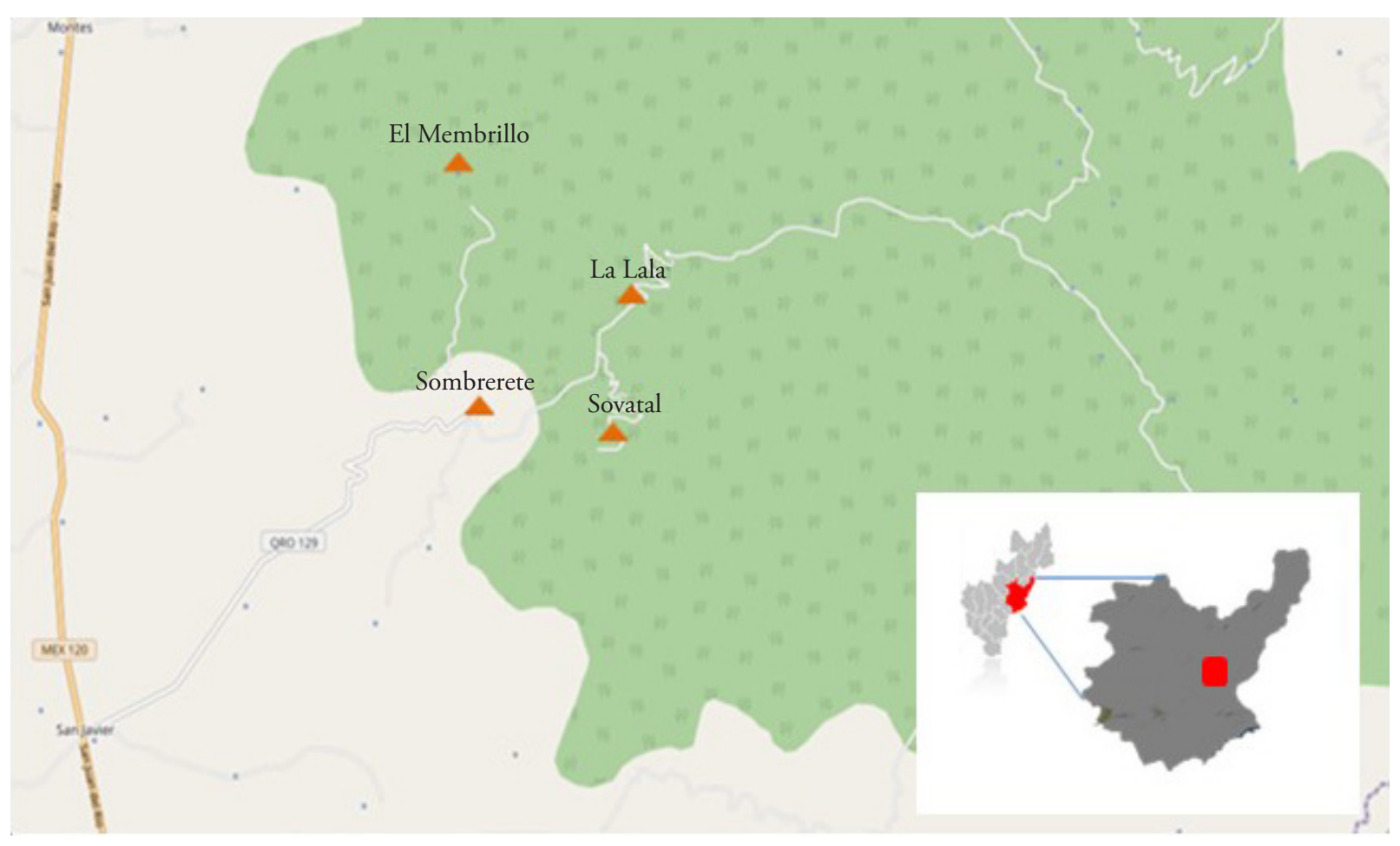

Figura 1. Ubicación de las localidades de la comunidad agraria Sombrerete, Querétaro.

Figure 1. Location of the localities of the agrarian community Sombrerete, Querétaro. 
la económicamente activa registrada como ocupada suma un total de 504 . El total es un referente respecto a la población ocupada en la minería comunitaria. De acuerdo con INEGI (1991) sensiblemente 23\% de la población de la comunidad agraria de Sombrerete no sabe leer ni escribir.

\section{MATERIALES Y MÉTODOS}

Se utilizó un enfoque mixto en el que se hace uso de técnicas cualitativas y cuantitativas. Inicialmente se realizó una visita de exploración a la comunidad agraria de Sombrerete. Se concertó una entrevista con el comisariado de bienes comunales de la comunidad en la que se obtuvo la anuencia para la realización del estudio y se recabó información general de la organización comunitaria para el aprovechamiento del mármol.

Para la recolección de la información cualitativa se aplicaron entrevistas semiestructuradas que permiten agregar preguntas adicionales para precisar conceptos y profundizar en temas importantes para el investigador (Hernández et al., 2010). Estas entrevistas se aplicaron al Comisariado de Bienes Comunales de la comunidad (una), expresidentes del Comisariado (tres) y Consejos directivos de las cooperativas de productores de mármol (tres), siendo un total de siete entrevistas. Con las entrevistas se obtuvo información sobre la historia del proceso agrario, actividades productivas en la comunidad, organizaciones existentes y características sobre sus sistemas de aprovechamiento y problemática comunitaria. La información cuantitativa se recolectó a través de un cuestionario con preguntas cerradas y codificadas diseñado para obtener datos de producción, comercialización, costos e ingresos de los productores de mármol. Estos datos fueron el insumo para relacionar el nivel organizativo de las cooperativas y su impacto en los cambios tecnológicos recientes, acceso al mercado, producción, ingresos y la opinión sobre el bienestar de la familia de los productores.

En la primera etapa realizada en los meses de marzo y abril de 2016, se aplicaron las entrevistas al Comisariado de bienes comunales y a los Consejos directivos de las cooperativas. En esta etapa se concertó con los Consejos directivos de las cooperativas la siguiente fase de entrevista a productores.

Para el caso de los expresidentes del Comisariado ejidal y productores de mármol, la determinación de

\section{MATERIALS AND METHODS}

A mixed approach was used where qualitative and quantitative techniques are used. Initially an exploration visit was made to the agrarian community of Sombrerete. An interview was arranged with the communal goods commissary from the community where the consent was obtained to perform the study and general information about the community organization was gathered for the exploitation of marble.

For the collection of the qualitative information, semi-structured interviews were applied that allow adding extra questions to specify concepts and delve into important themes for the researcher (Hernández et al., 2010). These interviews were applied to the Communal Goods Commissary of the community (one), former presidents of the Commissary (three), and directive Councils of the marble producing cooperatives (three), making a total of seven interviews. Information was obtained with the interviews about the history of the agrarian process, productive activities in the community, existing organizations and characteristics of their exploitation systems, and community problems. The quantitative information was collected through a questionnaire with closed and codified questions designed to obtain data about production, commercialization, costs and income of the marble producers. These data were the input to connect the organizational level of the cooperatives and their impact on recent technological changes, access to the market, production, income and the opinion on welfare of the producer's family.

In the first stage carried out during the months of March and April, 2016, interviews were applied to the Communal Goods Commissary and to the Directive Councils of the cooperatives. In this stage, the next phase of interviews with producers was arranged with the Directive Councils of cooperatives.

For the case of the former presidents of the ejido Commissary and marble producers, the determination of participants was the identification of key informants through the snowball method, where an interviewed individual would point to another who would be willing to participate and provide information. In a second stage, during the month of May, interviews were applied to former presidents of the Commissary and other producers 
los participantes fue la identificación de informantes clave a través del método bola de nieve, donde un individuo entrevistado indicaba a otro que estuviera dispuesto a participar y proporcionar información. En una segunda etapa en el mes de mayo se aplicaron entrevistas a expresidentes del Comisariados y otros productores socios de las cooperativas productoras de mármol. En la tercera etapa durante el mes de agosto se aplicaron los cuestionarios a un total de ocho productores de mármol, que fueran socios de las cooperativas. Del total de cinco cooperativas registradas con el Comisariado, fue posible obtener información de tres cooperativas, las cuales son consideradas como estudios de caso y cubren el ámbito del universo.

Para el análisis de datos se utilizó el Paquete Estadístico para las Ciencias Sociales (SPSS por sus siglas en inglés) versión 15.0 para Windows.

\section{RESULTADOS Y DISCUSIÓN}

\section{La cuestión agraria, recursos y actividades económicas en la comunidad}

La Comunidad agraria de Sombrerete cuenta con 8684 hectáreas que se reconocen con la resolución presidencial de 1984 (RAN, 2016b). Según el Comisariado actual de bienes comunales, en el año de 1966 inicia un periodo de incertidumbre en la comunidad en relación a la propiedad de la tierra, debido a que los documentos originales que acreditaban la posesión legítima de la tierra se quemaron en un incendio de las instancias comunales. La consecuente carencia de documentos sobre el derecho común de los recursos patrimoniales propició una serie de intentos para despojar a la comunidad de parte de sus bienes. La superficie en litigio por la posesión de la tierra que la Comunidad de Sombrerete tiene con pequeños propietarios y otras comunidades agrarias y ejidos colindantes suman un total de 912 hectáreas. Cabe subrayar según Caddy (2006) los efectos colectivos que tienen los esfuerzos realizados para proteger sus recursos, dentro de la estructura de los sistemas políticos que se basan en el manejo de la propiedad individual.

Las principales actividades productivas desarrolladas por la población de la Comunidad, en orden de importancia son: extracción de mármol, trabajo de construcción en la ciudad de Querétaro y en la ciudad de México, recolección de piñón como una who were partners in the marble producing cooperatives. In the third stage, during the month of August, questionnaires were applied to a total of eight marble producers who were partners of the cooperatives. Out of the total of five cooperatives registered with the Commissary, it was possible to obtain information from three cooperatives, which are considered as case studies and cover the scope of the universe.

The Statistical Package for Social Sciences (SPSS), version 15.0 for Windows, was used for data analysis.

\section{RESULTS AND DISCUSSION}

\section{The agrarian issue, resources and economic activities in the community}

The agrarian community of Sombrerete has 8,684 hectares that are recognized with the presidential resolution from 1984 (RAN, 2016b). According to the current Communal Goods Commissary, a period of uncertainty in the community began in the year 1966 related to land ownership, because the original documents that proved the legitimate ownership of the land were burnt in a fire of the communal facilities. The consequent lack of documents on the common right of the patrimonial resources fostered a series of attempts to dispossess the community of part of its goods. The surface in dispute over ownership of the land in the community of Sombrerete has small-scale owners and other agrarian communities and neighboring ejidos and it is a made up by a total of 912 hectares. According to Caddy (2006), it should be mentioned that the collective effects from efforts carried out to protect their resources must be highlighted, within the structure of the political systems that are based on the management of individual property.

The main productive activities developed by the population in the community in order of importance are: marble extraction, construction work in the city of Querétaro and in Mexico City, collection of pine nuts as a seasonal activity, and rainfed agriculture for auto-consumption. The land surface and its type of use are presented in Table 2.

The community has marble reserves distributed in the territory, which have not been quantified yet in their totality. Presently there are 47 hectares assigned to producers for the exploitation of marble. 
actividad estacionaria y agricultura de temporal para autoconsumo. La superficie de tierra y su tipo de uso se presentan en el Cuadro 2.

La Comunidad cuenta con reservas de mármol distribuidas en su territorio, las cuales aún no han sido cuantificadas en su totalidad. Actualmente son 47 hectáreas las asignadas a productores para el aprovechamiento de mármol.

La actividad de extracción de mármol tiene una destacada importancia para los productores, considerando que solamente entre las tres cooperativas entrevistadas generan 136 empleos para personas de la Comunidad. Además de los empleos generados entre transportistas y las empresas transformadoras.

\section{Características de los productores de mármol}

Los productores de mármol entrevistados de la Comunidad tienen una edad promedio de 50 años, en un rango de entre 37 a 54 años. El sexo predominante es el masculino (75\%). El estado civil predominante entre los entrevistados es la unión libre con un porcentaje de 62.5\%. De los entrevistados 100\% tienen la capacidad de leer y escribir. La escolaridad promedio es de primer grado de secundaria, tienen escolaridad mínima de tercer grado de primaria, hasta uno que cursó el bachillerato. El número de sus dependientes económicos es de uno hasta seis. La información de campo indica que la actividad económica complementaria más común entre los entrevistados es la agricultura, aunque sólo como una actividad de autoconsumo; sin embargo, se estima que $62.0 \%$ de los entrevistados no tiene actividades económicas complementarias y se dedican exclusivamente a la extracción de mármol.

Los productores de mármol hacen uso de diferentes fuentes de financiamiento. Para el pago de insumos (explosivos y diésel) y renta de maquinaria es con recursos propios del ingreso obtenido por las ventas del mármol; por su parte, empresas compradoras de mármol son la principal fuente externa de financiamiento para la adquisición de maquinaria necesaria para la extracción. El tiempo que llevan dedicándose a la actividad los productores entrevistados es de 8 y 10 años en promedio, aunque la variación es amplia, se encuentra en un rango de ocho hasta los treinta y ocho ańos trabajando en la extracción de mármol. El tiempo que tienen como socios de las organizaciones constituidas para la extracción mármol es de tres hasta dieciséis ańos.
Cuadro 2. Superficie de la tierra de la comunidad de acuerdo al tipo de uso de suelo.

Table 2. Land surface of the community according to the type of land use.

\begin{tabular}{lc}
\hline Tipo de uso del suelo o vegetación & $\begin{array}{c}\text { Superficie } \\
\text { (ha) }\end{array}$ \\
\hline Uso común & 4000 \\
Agricultura & 2000 \\
Zona de producción de mármol & 47 \\
Fundo poblacional & 2637 \\
\hline Total & 8684.0 \\
\hline
\end{tabular}

The activity of marble extraction has an outstanding importance for the producers, considering that just between the three cooperatives interviewed it generates 136 jobs for people in the community, in addition to the jobs generated among drivers and transforming companies.

\section{Characteristics of marble producers}

The marble producers from the community interviewed are on average 50 years old, within a range between 37 and 54 years. The predominant sex is masculine in $75 \%$. The predominant marital status among interview respondents is civil union with a percentage of $62.5 \%$. All of the interview respondents $(100 \%)$ have the ability to read and write. Average schooling is first secondary and minimal schooling is third grade primary, and one person finished high school. The number of economic dependents is one to six. The field information indicates that the most common complementary economic activity among interview respondents is agriculture, although only as an activity for auto-consumption; however, it is estimated that $62.0 \%$ of the interview respondents do not have complementary economic activities and they are devoted exclusively to marble extraction.

The marble producers make use of different sources of financing. For payment of inputs (explosives and diesel) and machinery rental, it is with resources of their own from income obtained from marble sales; in turn, the companies that buy marble are the main external source of financing for the purchase of machinery necessary for the extraction. The time that they have been devoted to the activity mentioned by interview respondents is 8 and 10 years on average, although the variation is wide; it is found within a range of eight to thirty-eight years working in marble 


\section{Organización comunitaria para el aprovechamiento del mármol}

La Asamblea de comuneros es el órgano supremo de toma de decisiones de interés para la comunidad, en la que participan según reglamento todos los comuneros. El Comisariado de Bienes Comunales es el órgano responsable de la ejecución de los acuerdos de la Asamblea y de la representación y gestión administrativa de la comunidad. Está constituido por un Presidente, un Secretario, y un Tesorero, propietarios y sus respectivos suplentes. El Consejo de Vigilancia está integrado por un Presidente, y dos Secretarios, propietarios y sus respectivos suplentes. Las facultades de este órgano son vigilar que los actos del Comisariado se ajusten a lo dispuesto por la ley y en el reglamento interno de la comunidad, así como revisar las cuentas y operaciones del Comisariado, para darlas a conocer a la asamblea y, en su caso denunciar ante esta las irregularidades encontradas (Cámara de diputados 2012).

En la comunidad agraria de Sombrerete, entre otras decisiones la Asamblea decide sobre la autorización de solicitudes individuales para la asignación de un banco de mármol a un aspirante a usufructuario. La actividad de extracción de mármol se ha configurado desde la década de 1970, año aproximado en que la comunidad expulsó a personas externas que extraían el producto sin dejar regalías a la comunidad. A partir de ese ańo, la comunidad agraria de Sombrerete ha establecido un conjunto de relaciones e instituciones que rigen el actuar de los diferentes actores involucrados (Figura 2) en la extracción y comercialización del mármol. De manera similar, en otras regiones mineras donde se explotan rocas dimensionables se han establecido empresas sociales para el manejo de estos recursos (Silva et al., 2012). Los actores que participan en la cadena de producción de mármol, son aquellos que están vinculados a la actividad en alguna o varias de las etapas o actividades.

Los principales actores internos que pertenecen a la comunidad tienen funciones bien definidas establecidas en las instituciones comunales según disposición reglamentaria, en asociación con aquellas que se han creado para regular la extracción de mármol (Cuadro 3).

Los comuneros y los avecindados de la comunidad tienen el derecho de obtener un permiso para extraction. The time they have as partners in the organizations constituted for marble extraction is three to sixteen years.

\section{Community organization for the exploitation of marble}

The Comunero Assembly is the supreme decisionmaking agency of interest for the community, where all the comuneros participate according to the regulations. The Communal Goods Commissary is the authority responsible for the execution of the Assembly's agreements and for the representation and administrative management of the community. It is constituted by a President, a Secretary, and a Treasurer, owners and corresponding substitutes. The Vigilance Council is made up by a President and two Secretaries, owners and corresponding substitutes. The faculties of this body are to monitor that the Commissary's actions adjust to what is established by the law and the internal regulations of the community, as well as to review the accounts and operations of the Commissary, to communicate them to the assembly and, if applicable, to denounce these irregularities found (Cámara de diputados 2012).

In the agrarian community of Sombrerete, among other decisions, the Assembly decides on the authorization of individual requests for the allotment of a marble bank to an aspiring beneficial owner.

The activity of marble extraction has been configured since the decade of the 1970s, approximate years when the community expelled foreign people who extracted the product without leaving profit to the community. Since 1970, the agrarian community of Sombrerete has established a set of relationships and institutions that rule the actions of the different actors involved (Figure 2) in the extraction and commercialization of marble. Similarly, in other mining regions where dimensionable rocks are exploded, social companies have been established for the management of these resources.

The actors who participate in the marble production chain are those that are linked to the activity in one or several of the stages or activities.

The main internal actors that belong to the community have well-defined functions established in the communal institutions according to the regulatory provision, in association with those that 


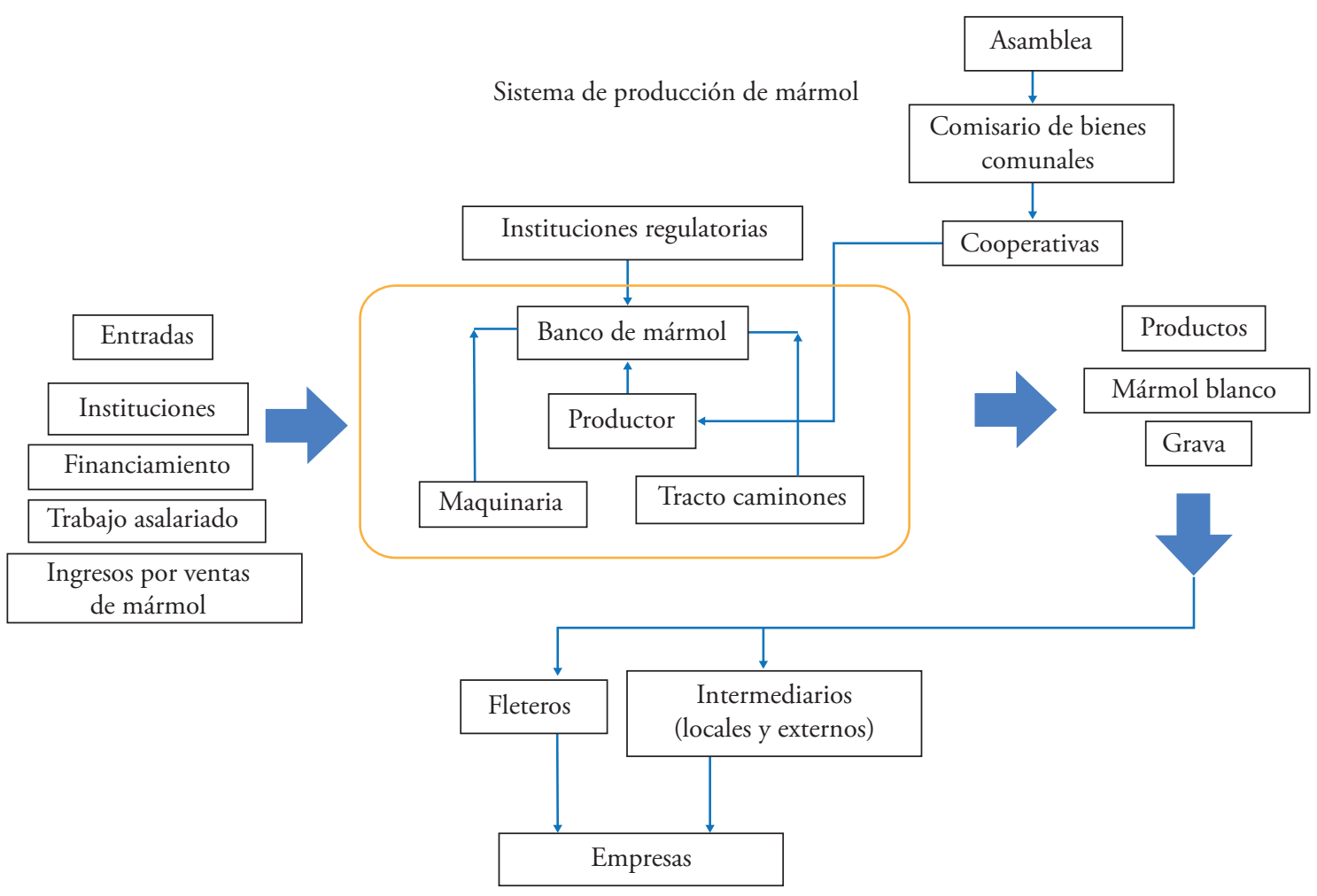

Figura 2. Sistema de producción de mármol en la Comunidad de Sombrerete.

Figure 2. Marble production system in the Community of Sombrerete.

el usufructo de mármol, a través de un proceso que inicia con la presentación de una solicitud al Comisariado Ejidal. Posteriormente, la Asamblea de Comuneros hace un análisis de la solicitud considerando el estado del solicitante en cuanto al cumplimiento de obligaciones en la comunidad, al final se emite un dictamen, que puede ser de aprobación, en cuyo caso have been created to regulate marble extraction (Table 3).

Comuneros and residents of the community have the right to obtain a permit to usufruct marble, through a process that begins with the presentation of a request to the Ejido Commissary. Later, the Comunero Assembly makes an analysis of the

Cuadro 3. Actores internos en la producción de mármol de la comunidad.

Table 3. Internal actors in the community's marble production.

\begin{tabular}{|c|c|}
\hline Actor & Funciones o atribuciones \\
\hline Asamblea de Comuneros & $\begin{array}{l}\text { Norma y establece los requisitos internos para el aprovechamiento del mármol, autoriza o } \\
\text { rechaza las solicitudes para el usufructo del mármol. }\end{array}$ \\
\hline $\begin{array}{l}\text { Comisariado ejidal (en representación } \\
\text { de la comunidad) }\end{array}$ & $\begin{array}{l}\text { Ejecuta las decisiones o acuerdos de la Asamblea de Comuneros, verifica el cumplimiento } \\
\text { de la normativa ante dependencias de los tres órdenes de gobierno. }\end{array}$ \\
\hline $\begin{array}{l}\text { Cooperativa de productores de } \\
\text { mármol (banqueros o marmoleros) }\end{array}$ & $\begin{array}{l}\text { Adquiere el permiso de usufructo de mármol, construye la infraestructura de caminos } \\
\text { para la extracción de mármol, realiza el aprovechamiento de mármol directamente en el } \\
\text { terreno, paga los permisos y licencias de operación, gestiona ante las instancias financieras } \\
\text { los apoyos para el financiamiento de la actividad productiva e investiga y establece } \\
\text { acuerdos con empresas o intermediarios compradores de mármol, realiza control de } \\
\text { calidad del producto en campo, observa la normativa interna y externa para el usufructo } \\
\text { de mármol. }\end{array}$ \\
\hline
\end{tabular}


termina el trámite. Si el dictamen fuera de rechazo, se recomienda al solicitante cumplir con sus obligaciones como comunero o avecindado para hacer la solicitud en otro momento. El trámite puede tardar dos meses si el comunero cumple con los requisitos, o más si no cumple. Al respecto Ostrom (1990) señala que los dueńos de un recurso común son capaces de crear instituciones para controlar las formas de uso y acceso al recurso que comparten.

La comunidad ha establecido requisitos para otorgar el usufructo de mármol a un comunero o avecindado, estos son: asistir a asambleas de la comunidad, cumplir con faenas convocadas por el Comisariado, participar en la verificación y mantenimiento de cercado perimetral de la comunidad, cumplir con usos y costumbres y tradiciones religiosas, aportar cooperación en las escuelas, cooperar para las fiestas tradicionales, asistir a las actividades de defensa de la tierra. Cuando ya se es comunero, los requisitos enlistados se convierten en obligaciones y se agregan las siguientes: participar en los procesos para la consecución de los permisos de operación y hacer las aportaciones correspondientes, y hacer el pago correspondiente a regalías para la comunidad (pago por "saqueo").

La asamblea general de comuneros ha establecido las disposiciones aplicables a aquellos productores de mármol que no se apeguen a lo estipulado en el contrato de usufructo y otras disposiciones que la asamblea acuerde (Cuadro 4). No obstante, existe un marco regulatorio institucional que determina las políticas y responsabilidades del ramo productivo del mármol.

Esta normativa determina el uso y conservación de los recursos entorno a la explotación del mármol, así como seguridad de los trabajadores y aspectos de índole técnico (Cuadro 5). La falta de aplicabilidad de esta normativa implica la cancelación de la extracción del mármol. Es oportuno señalar que este tipo de requisitos y sanciones por request considering the state of the requester in terms of compliance with obligations in the community, in order for a ruling to be issued eventually, which may be of approval, in which case the procedure ends. If the ruling is rejection, it is recommended that requester fulfill his obligations as comunero or resident in order to make the request at another moment. The procedure can take two months if the comunero fulfills the requirements, or more if he does not. In this regard, Ostrom (1990) points out that the owners of a common resource are capable of creating institutions to control the forms of use and access to the resource they share.

The community has established requirements to grant the usufruct of marble to a comunero or resident, which are: attending community assemblies, complying with tasks convened by the Commissary, participating in the verification and maintenance of the perimeter fencing of the community, complying with the uses and customs as well as religious traditions, contributing to the schools, cooperating for the traditional festivities, attending the activities in defense of land. When someone is a comunero, the requirements enlisted are made into obligations and the following are added: participating in the processes for attaining the operation permits and making the corresponding contributions, and making the corresponding payment to royalties for the community (payment for "pillage").

The general comunero assembly has been established by dispositions applicable to those marble producers who do not follow what is stipulated in the contract of usufruct and other dispositions that the assembly agrees to (Table 4). However, there is an institutional regulatory framework that defines the policies and responsibilities of the marble productive branch.

These regulations determine the use and conservation of resources around the exploitation of marble, as well as the safety of the workers and

Cuadro 4. Sanciones por incumplimiento de obligaciones.

Talble 4. Sanctions for breach of obligations.

\begin{tabular}{ll}
\hline \multicolumn{1}{c}{ Causa de la sanción } & Sanción que se aplica \\
\hline $\begin{array}{l}\text { Incumplir con obligaciones o acuerdos de la asamblea } \\
\text { Hacer caso omiso o reincidir en el cumplimiento de } \\
\text { obligaciones }\end{array}$ & $\begin{array}{l}\text { El comisariado hace llamada de atención al infractor y se le invita a } \\
\text { subsanar la falta. } \\
\text { Suspensión del permiso de usufructo de mármol. }\end{array}$ \\
$\begin{array}{l}\text { Dar información que sólo le pertenece a la comunidad } \\
\text { Multa de \$5000.00 a la persona que cometa esta falta }\end{array}$
\end{tabular}


Cuadro 5. Instituciones normativas involucradas en la producción y comercialización de mármol.

Table 5. Normative institutions involved in the production and commercialization of marble.

\begin{tabular}{ll}
\hline \multicolumn{1}{c}{ Institución } & \multicolumn{1}{c}{ Funciones } \\
\hline $\begin{array}{l}\text { Secretaria de Medio Ambiente y } \\
\text { Recursos Naturales (SEMARNAT) }\end{array}$ & $\begin{array}{l}\text { Orientar las acciones encaminadas a revertir el deterioro ecológico; proteger el medio } \\
\text { ambiente; evitar la pérdida de biodiversidad; Contribuir a la conservación de los } \\
\text { ecosistemas y validación de estudios de impacto ambiental }\end{array}$ \\
$\begin{array}{l}\text { Comisión Nacional del Agua } \\
\text { (CONAGUA) }\end{array}$ & $\begin{array}{l}\text { Supervisar que se cumplan los requisitos para emitir el permiso de derechos de paso en } \\
\text { cauces de arroyos. }\end{array}$ \\
$\begin{array}{l}\text { Secretaría de la Defensa Nacional } \\
\text { (SEDENA) }\end{array}$ & Autorizar el manejo de explosivos que se utilizan en la extracción de mármol. \\
$\begin{array}{l}\text { Secretaría del Trabajo y Previsión } \\
\text { Social (STPS). }\end{array}$ & $\begin{array}{l}\text { Supervisar el cumplimiento de la normativa en materia de seguridad en el trabajo. } \\
\text { Secretaría de Desarrollo Sustentable } \\
\text { del Estado de Qurétaro (SEDESU) }\end{array}$ \\
$\begin{array}{l}\text { Proporcionar asesoría en los aspectos técnicos que determinan la actividad minera, } \\
\text { apoyo técnico y promoción de áreas con potencial geológico-minero, promociona } \\
\text { las áreas con potencial geológico-minero del Estado de Querétaro con inversionistas } \\
\text { nacionales y extranjeros Teniendo como principales beneficiarios a los pequeños y } \\
\text { medianos mineros. }\end{array}$ \\
$\begin{array}{l}\text { Presidencia Municipal de Cadereyta } \\
\text { Autorizar el cambio de uso de suelo a nivel municipal }\end{array}$ \\
\hline
\end{tabular}

incumplimiento ilustran de manera precisa, porque los sistemas de propiedad común han sido reconocidos (Caddy, 2006), ya que han proporcionado lecciones valiosas para el manejo y el desarrollo institucional. Esto debido a que las instituciones indígenas tienen una acentuada capacidad para adaptarse a las circunstancias cambiantes a través del tiempo.

\section{La comercialización y actores de la normativa pública}

El análisis de la cadena de valor muestra que el alcance en la agregación de valor es prácticamente limitado para la extracción del mármol o sea la etapa primaria, teniendo en cuenta que la transformación o beneficio necesario del mármol para su comercialización se encuentra fuera de la comunidad, ya sea en empresas instaladas en la cabecera municipal o en la ciudad de Querétaro. Además se registra que los movimientos a los sitios de beneficiado se realizan por empresas de transporte ajenas a las sociedades cooperativas productoras, o de los productores individuales (Cuadro 5).

Con relación al marco institucional gubernamental y las dependencias involucradas en la normativa regulatoria oficial, en el Cuadro 6 se enlistan las dependencias y sus responsabilidades referentes al ramo productivo del mármol. aspects of technical nature (Table 5). The lack of applicability of this norm implies the cancellation of marble extraction. It is important to point out that this type of requirements and sanctions from breach of obligations illustrates accurately why the common property systems have been recognized (Caddy, 2006), since valuable lessons have been provided for management and institutional development. This is because the indigenous institutions have an accentuated ability to adapt to changing circumstances throughout time.

\section{Commercialization and actors of the public regulations}

The analysis of the value chain shows that the reach in adding value is practically limited for marble extraction, that is, the primary stage, taking into account that the necessary transformation or benefit from marble for its commercialization is outside of the community, whether in companies installed in the municipal township or in the city of Querétaro. In addition it is shown that the movements to the processing sites are performed by outside transport companies to the producing cooperative societies, or of individual producers (Table 5).

Related to the government institutional framework and the agencies involved in the official 
Es posible considerar con la información del binomio comercialización-normativa que se ilustra, nos muestra la convergencia de intereses en relación a la apropiación de rentas a diferentes escalas sobre los recursos naturales. A sobremanera sobre este tipo de recursos de comunidades indígenas, teniendo en cuenta sus limitaciones para acceder a los trámites y recursos institucionales, así como a los financieros que les permitan apropiarse de la cadena en su totalidad. Cabe señalar que los costos de transacción para cubrir la normativa establecida son demasiado onerosos para sus condiciones económicas.

\section{Organización del sistema producción de mármol, comercial e institucional}

Los permisos autorizados a comuneros o avecindados por la asamblea comunitaria para el aprovechamiento del mármol en forma individual, han evolucionado hacia la conformación de colectivos de productores asociados en la figura de cooperativas. En la comunidad agraria de Sombrerete se constituyeron tres cooperativas para socializar y disminuir el costo de los trámites y permisos ante la SEMARNAT. Actualmente, todos los usufructuarios del mármol de la comunidad están asociados en términos formales en la figura asociativa de cooperativa. Esta modalidad como la mejor opción que les permite acceder al mercado, debido a que las empresas compradoras así lo exige, a parir del año 2013. De esta forma, debe existir una figura asociativa legalmente constituida como requisito para comprarles el mármol. Históricamente en México se han impulsado las cooperativas mineras con la regulatory law, in Table 6 the agencies and their responsibilities referring to the productive branch of marble are listed.

With the information of the commercializationnormative pairing that is illustrated, it is possible to consider that it shows the convergence of interests in relation to the appropriation of rents from natural resources at different scales. Mostly about this type of resources from indigenous communities, taking into account their limitations to gain access to institutional procedures and resources, as well as to the financial resources that allows them to appropriate the chain in its entirety. It should be pointed out that the transaction costs to cover the regulations established are too expensive for their economic conditions.

\section{Organization of the marble production system, commercial and institutional}

The permits authorized to comuneros or residents by the community assembly for the exploitation of marble individually have evolved toward the conformation of collectives of producers associated under the figure of cooperatives. Three cooperatives were constituted in the agrarian community of Sombrerete to socialize and decrease the cost of the procedures and permits before the SEMARNAT. Currently, all the beneficial owners of marble from the community are associated in formal terms in the associative figure of cooperative. This modality is the best option that allows them to gain access to the market because the purchasing companies demand it since the year 2013. Therefore, there must be a legally constituted associative figure as requisite to

Cuadro 6. Cadena de valor para la comercialización.

Table 6. Value chain for the commercialization.

Eslabón

Fletero (propietario de vehículos que transportan el mármol a las empresas)

Intermediarios

Empresa compradora-transformadora de mármol
Funciones o atribuciones
Envían sus vehículos para el transporte de mármol de los bancos a la empresa. Rentan o venden maquinaria (retroexcavadora y compresor) a los productores de mármol.

Compran mármol a los productores directamente en los bancos para revender a las empresas. Pueden ser del mismo municipio de Cadereyta o del estado de Querétaro, o del estado de Hidalgo.

Compra el mármol en greña (pedacería) a los productores; establece las especificaciones para adquirir el producto; así como las condiciones de transacción para la realización del pago del mármol y el precio del mármol; en ciertos casos contrata a los fleteros (transportistas) que transportan el mármol de los bancos a la planta transformadora. 
finalidad de reducir la inversión extranjera en este sector (Valladares, 2017).

\section{Cooperativa Puerto La Peña, S. C. de R. L. de C. V.}

De acuerdo con lo declarado por el Consejo de Administración y los productores entrevistados, esta cooperativa no cuenta con elementos de organización interna formales, pues carece de manuales de operación, reglamento interno, no tiene estrategias de comunicación interna consolidada y la interacción entre los socios se limita a reuniones para distribución de ingresos y resolución de la problemática urgente.

Respecto al clima organizacional, tanto el Consejo de Administración de la cooperativa como los socios entrevistados declararan sentirse insatisfechos por pertenecer a la cooperativa, ya que no perciben beneficios suficientes en ingreso y acceso a financiamiento, ni en apoyos gubernamentales. Las acciones colectivas de la cooperativa son el pago de impuestos y gastos administrativos y pago de permisos de operación, tampoco cuenta con planes de acción, sólo tiene acciones programadas para mejorar la administración y el proceso productivo, se atienden los asuntos o problemas urgentes en el momento que se presentan.

De acuerdo a las características descritas en los aspectos de organización interna y clima organizacional, se observa que la cooperativa tiene nivel organizativo muy limitado que restringe el funcionamiento interno óptimo según los principios de esta figura y los beneficios sociales y económicos que los productores obtienen podrían logra por el hecho de estar organizados.

En el aspecto financiero, los socios hacen aportaciones para pago de impuestos y gastos administrativos que se les descuenta de los ingresos por venta de mármol, no se realizan gestiones de recursos externos como organización, la cooperativa tiene una deuda por la cantidad de $\$ 80000.00$ que corresponde al pago de multa por realizar la actividad productiva fuera del perímetro autorizado por la SEMARNAT, no se realiza reparto de utilidades, considerando que cada socio recibe los ingresos generados de forma individual. En el aspecto de mercado, la cooperativa firma un contrato con la principal empresa compradora de mármol que es Omya México, S. A. de C. V., la cual establece volumen, cantidad y calidad. buy the marble. Historically in Mexico the mining cooperatives have been promoted with the aim of reducing foreign investment in this sector (Valladares, 2017).

\section{Cooperativa Puerto La Peña, S. C. de R. L. de C V.}

According to what was declared by the Administration Council and the producers interviewed, this cooperative does not have elements of formal internal organization, since it lacks operation manuals, internal rules, does not have consolidated internal communication strategies, and the interaction between the members is limited to meetings for the distribution of income and resolution of the urgent problem.

Regarding the organizational climate, both the Administration Council of the cooperative and the members interviewed declared feeling unsatisfied by belonging to the cooperative, since they do not obtain sufficient benefits in income and access to financing, or in government supports. The collective actions of the cooperative are payment of taxes and administrative expenses and payment of operation permits. The cooperative also does not have action plans, it only has programmed actions to improve the administrative and productive process, and the urgent issues or problems are addressed when they come up.

According to the characteristics described in the aspects of internal organization and organizational climate, it is observed that the cooperative has a very limited organizational level that restricts optimal internal functioning according to the principles of this figure and the social and economic benefits that producers obtain could be achieved because they are organized.

In the financial aspect, the members make contributions for tax payment and administrative expenses that are discounted from the income from marble sales; they do not carry out management of external resources as an organization; the cooperative has a debt in the amount of $\$ 80,000.00$ that corresponds to the payment of a fine from performing the productive activity outside the perimeter authorized by SEMARNAT; there is no profit sharing, considering that each member receives the income generated individually. In the market 
La participación en la cadena de valor se limita al primer eslabón que es la extracción en banco. Los productos que se ofertan son mármol blanco Querétaro y mármol gris San Luis en greña o pedacería de 30.0 por $20.0 \mathrm{~cm}$ para la industria de triturado y molienda como carbonatos de calcio. En el aspecto de infraestructura, maquinaria y equipo, la cooperativa no cuenta con activos propios, sólo algunos socios cuentan con maquinaria (retroexcavadora y compresor de aire).

\section{Cooperativa del Semidesierto S. C. de R. L. de C. V.}

La cooperativa no cuenta con manuales de operación, ni reglamento interno, su estrategia de comunicación interna consiste en reuniones bimensuales, la interacción entre los socios se caracteriza por la formación de grupos de socios de tres o cuatro integrantes que comparten equitativamente costos e ingresos de la producción. Con relación al clima organizacional, los socios declararon sentirse satisfechos por pertenecer a la cooperativa, ya que perciben beneficios como acceso al mercado, financiamiento y asegurar ingresos, las acciones colectivas como cooperativa son el pago de impuestos y gastos administrativos y pago de permisos de operación, tampoco cuenta con planes de acción para el mejoramiento productivo u organizativo. De acuerdo a las características encontradas en los aspectos de organización interna y clima organizacional, la cooperativa se encuentra en un nivel organizativo medio que limita en algunos aspectos el funcionamiento interno de la organización.

En el aspecto financiero, los socios hacen aportaciones para pago de impuestos y gastos administrativos, se hacen gestiones de apoyos ante dependencias gubernamentales y empresas compradoras. Las deudas de la cooperativa son para pagos de permisos de operación ante la SEMARNAT; no se realiza reparto de utilidades, puesto que cada grupo o socio recibe sus ingresos por separado. En el aspecto de mercado, la cooperativa firma un contrato con la principal empresa compradora de mármol que es Omya México, S. A. de C. V., misma que establece volumen, cantidad y calidad. La participación en la cadena productiva se limita al primer eslabón de la cadena que es la extracción en banco, los productos que se ofertan son mármol blanco Querétaro y mármol gris San Luis en greña o en pedacería de $30 \times 20 \mathrm{~cm}$ para la industria aspect, the cooperative signs a contract with the main marble-purchasing company, Omya México, S. A. de C. V., which establishes the volume, quantity and quality.

The participation in the value chain is limited to the first link that is the extraction at the bank. The products that are offered are white Querétaro marble and grey San Luis marble in pieces of 30.0 by $20.0 \mathrm{~cm}$ for the industry of grinding and milling as calcium carbonates. In the aspect of infrastructure, machinery and equipment, the cooperative doesn't have assets of its own, only some members have machinery (retro-excavator and air compressor).

\section{Cooperativa del Semidesierto S. C. de R. L. de C. V.}

The cooperative does not have operation manuals or internal regulations, its internal communication strategy consists in bimonthly meetings, and the interaction between members is characterized by the formation of member groups of three or four partners that share costs and income from the production equally. Regarding the organizational climate, the members declared feeling satisfied by belonging to the cooperative, since they perceive benefits such as access to the market, financing and ensuring income, the collective actions as a cooperative are payment of taxes and administrative expenses, and payment of operation permits; it also doesn't have action plans for productive or organizational improvement. According to the characteristics found in the aspects of internal organization and organizational climate, the cooperative is at an intermediate organizational level that limits the internal functioning of the organization in some aspects.

In the financial aspect, the members make contributions to pay taxes and administrative expenses, and they make negotiations to receive support from government agencies and purchasing companies. The debts of the cooperative are for payments of operation permits before the SEMARNAT; there is no profit sharing, since each group or member receives their income separately. In the market aspect, the cooperative signs a contract with the main marble-purchasing company, Omya México, S. A. de C. V., which establishes the volume, quantity and quality. The participation in the productive chain is limited to the first link of 
de triturado y molienda como carbonatos de calcio y gravas de diferentes tamaños. En el aspecto de infraestructura, maquinaria y equipo, la cooperativa no cuenta con activos propios, los socios cuentan con maquinaria (retroexcavadora y compresor de aire) de manera individual, aunque actualmente se encuentran haciendo gestiones con la empresa Omya México, S. A. de C. V. para el préstamo que posibilite la adquisición de maquinaria moderna con la finalidad de aumentar los niveles de producción.

\section{Zoyatalito S. C. de R. L. de C. V.}

La cooperativa no cuenta con manuales de operación, ni reglamento interno, su estrategia de comunicación es mantenerse informados constantemente, ya que interactúan en el área de trabajo y se coordinan para resolver los asuntos de la producción y administración. El clima organizacional es favorable ya que el consejo de administración de la cooperativa declaró que los socios se sienten satisfechos por pertenecer a la cooperativa, debido a que perciben beneficios como acceso al mercado, financiamiento y asegurar ingresos necesarios para el sustento familiar. Todas las acciones que se realizan para producción, comercialización y administración son consensuadas y aceptadas por todos los socios, no cuenta con planes de acción para el mejoramiento productivo u organizativo. De acuerdo con lo enunciado en los aspectos de organización interna y clima organizacional se observa que la cooperativa se encuentra en un nivel organizativo alto que le permite agilizar el proceso productivo y responder efectivamente ante escenarios adversos en el entorno.

En el aspecto financiero, los socios no hacen aportaciones, se hacen gestiones de apoyos ante empresas compradoras de mármol, la cooperativa actualmente tiene deuda con la empresa Omya México, S. A. de C. V. por un monto de $\$ 600000.00$ que se utilizó para la adquisición de maquinaria que la misma empresa proporcionó, el reparto de utilidades se realiza de manera semanal de acuerdo a la contribución de los socios en cuanto a trabajo y colaboración. En el aspecto de mercado, la cooperativa firma un contrato con la principal empresa compradora de mármol que es Omya México, S. A. de C. V. La participación en la cadena productiva se limita al primer eslabón (extracción en banco), los productos que se ofertan son mármol blanco Querétaro y mármol gris San Luis en the chain which is the extraction from the bank; the products that are offered are white Querétaro marble and grey San Luis marble in pieces of $30 \times 20$ $\mathrm{cm}$ for the grinding and milling industry as calcium carbonates and gravel of different sizes. In the aspect of infrastructure, machinery and equipment, the cooperative does not have its own assets, the members have machinery (retro-excavator and air compressor) individually, although currently they are negotiating with the company Omya México, S. A. de C. V. for the loan that makes possible the purchase of modern machinery with the aim of increasing the production levels.

\section{Zoyatalito S. C. de R. L. de C. V.}

The cooperative does not have operation manuals, or internal regulations; its communication strategy is to keep constantly informed, since they interact in the work area and coordinate to solve the issues of production and administration. The organizational climate is favorable since the administration council declared that the members feel satisfied from belonging to the cooperative, because they perceive benefits such as access to the market, financing and ensuring the necessary income for family sustenance. All the actions that are carried out for production, commercialization and administration are consensual and accepted by all members; they do not have action plans for productive or organizational improvement. According to the statements made about the aspects of internal organization and organizational climate, it is observed that the cooperative is found in a high organizational level that allows accelerating the productive process and responding effectively in face of adverse scenarios in the environment.

In the financial aspect, the members do not make contributions, negotiations are made before marblepurchasing companies, and the cooperative currently has a debt with the company Omya México, S. A. de C. V. in the amount of $\$ 600000.00$ that was used to purchase machinery that the company provided; profit sharing is done weekly according to the contribution of the members in terms of work and collaboration. In the market aspect, the cooperative signs a contract with the main marblepurchasing company, Omya México, S. A. de C. V. The participation in the production chain is limited to the first link (bank extraction); the products 
greña o pedacería de $30 \times 20 \mathrm{~cm}$. En el aspecto de infraestructura, maquinaria y equipo, la cooperativa cuenta con maquinaria (retroexcavadora y compresor de aire) y equipos propios.

Si bien la constitución de cooperativas en la comunidad agraria de Sombrerete fue un mecanismo para tener acceso a la comercialización del mármol, se percibe que enfrentan limitantes asociadas a sus planes organizativos y son figuras formadas para cubrir requisitos para acceder a mercados. Esto implica la necesidad de establecer estructuras organizacionales funcionales que permitan definir planes y estrategias para eficientizar la extracción y comercialización a mediano y largo plazo; de esta forma la organización entorno a este tipo de minería puede tener ventajas comparativas. En la comarca del Mármol (Almería, España), se han promovido procesos organizativos y de planificación que han generado un desarrollo endógeno local lo que ha favorecido su competitividad y sustentabilidad en el uso del mármol (Carretero $e t$ al., 2018). Modelos que bien se pueden ajustar a la comunidad de Sombrerete.

\section{Nivel organizativo de las cooperativas y el acceso al mercado}

La constitución de las cooperativas ha permitido a los productores de mármol conseguir los permisos necesarios para el aprovechamiento y abaratar los costos de tales permisos. Con ello, las cooperativas y los productores de mármol han logrado cubrir el requisito para establecer tratos con empresas e intermediarios que compran el mármol. Las cooperativas con mayor nivel organizativo tienden a establecer los contactos con el mayor número de agentes compradores (Cuadro 7).

Es notoria la inexistencia de una organización de segundo nivel o integrador entre las cooperativas, que les permita en conjunto mejorar las condiciones de precios y las exigencias sobre la calidad de los productos, así por ejemplo se registra que venden sus productos en forma individual a dos grandes empresas beneficiadoras. En su caso, según los registros anteriores debido a una diversidad de alcances organizacionales y en muchos casos niveles de organización cooperativa muy limitados al interior de ellas, y reafirmando así como entre ellas. Sea que no han logrado espacios organizados de poder para negociar de mejor manera la comercialización de sus recursos. offered are white Querétaro marble and grey San Luis marble in pieces of $30 \times 20 \mathrm{~cm}$. In the aspect of infrastructure, machinery and equipment, the cooperative has machinery (retro-excavator and air compressor) and equipment of their own.

Although the constitution of cooperatives in the agrarian community of Sombrerete was a mechanism to gain access to commercialization of marble, it is perceived that they face limitations associated to their organizational plans and are figures formed to cover the requirements to gain access to markets. This implies the need to establish functional organizational structures that allow defining plans and strategies to make the extraction and commercialization more efficient in the medium and long term; thus, the organization around this type of mining can have comparative advantages. In the region of Mármol (Almería, Spain), organizational and planning processes have been promoted which have generated local endogenous development that has favored their competitiveness and sustainability in the use of marble (Carretero et al., 2018). These models can adjust well to the community of Sombrerete.

\section{Organizational level of the cooperatives and access to the market}

The constitution of the cooperatives has allowed the marble producers to attain the permits necessary for the exploitation and reducing the costs of such permits. With this, the marble cooperatives and producers have managed to cover the requirement to establish deals with companies and intermediaries that buy the marble. The cooperatives with higher organizational level tend to establish contacts with the highest number of purchasing agents (Table 7).

The existence of a second-level or integrating organization among the cooperatives is noticeable, which allows them as a whole to improve the conditions of prices and the demands on the quality of the producers, and for example this is how it is recorded that their products are sold individually to two large processing companies. In this case, according to the prior records, due to various organizational reaches and in many cases quite limited cooperative levels of organization inside them, and thus reaffirming it among them. This is why they have not achieved organized spaces of power to negotiate in the commercialization of their 
Cuadro 7. Número de empresas con las que comercializan las cooperativas.

Table 7. Number of companies with which the cooperatives trade.

\begin{tabular}{ccl}
\hline \multicolumn{1}{c}{ Nombre de la cooperativa } & $\begin{array}{c}\text { Número de } \\
\text { empresas }\end{array}$ & \multicolumn{1}{c}{ Nombre de las empresas } \\
\hline Puerto La Peña, S. C. de R. L. de C. V. & 3 & $\begin{array}{l}\text { Omya México, S. A. de C. V.; Química ATSA, S. A. de C. V. y } \\
\text { otra no mencionada }\end{array}$ \\
Semidesierto, S. C. de R. L. de C. V. & 6 & $\begin{array}{l}\text { Omya México, S. A. de C. V.; Química ATSA, S. A. de C. V.; } \\
\text { Intermediarios del Estado de Hidalgo; Fletero-Provedor de } \\
\text { maquinaria. }\end{array}$ \\
Soyatalito S. C. de R. L. de C. V. & 2 & $\begin{array}{l}\text { Omya México, S. A. de C. V.; Química ATSA, S. A. de C. V. y } \\
\text { otras }\end{array}$ \\
\hline
\end{tabular}

Un elemento a destacar es que los proyectos mineros han desencadenado diversos conflictos sociales y ambientales; los cuales son concesiones de exploración y explotación a grandes consorcios nacionales e internacionales, caracterizados por procesos extractivos, y degradativos de los territorios, de exclusión social (Gudynas, 2013, Valladares, 2018). En el caso de Sombrerete, no se han reportado conflictos entre los actores involucrados en el proceso de extracción y comercialización del mármol, el hecho de ser una minería de tipo social, ha ejercido cierto control sobre la apropiación de los recursos y su conservación.

El volumen de venta de mármol es un indicador importante de la capacidad de producción y del acceso al mercado, el cual posibilita a los productores planear la producción, así como establecer compromisos para la capitalización de la empresa y conseguir préstamos para la compra de maquinaria y equipo. En el Cuadro 8 se observa una clara tendencia en relación a que las cooperativas con un mayor nivel organizativo son aquellas que tienen mayores volúmenes de venta de mármol.

A primera vista puede pasar inadvertido, sin embargo las unidades de producción entrevistadas en las tres cooperativas producen mensualmente $7475 \mathrm{t}$ de mármol blanco y gris, mismas que representan de 750 a 800 viajes a las plantas transformadoras y sensiblemente $250 \mathrm{t} /$ día, Importancia sustantiva en la generación de empleo a diferencia de la gran minería extractiva. Además, cabe resaltar, de acuerdo con Jennings (2012) como a pesar de los importantes esfuerzos realizados en muchos países, la tasa mundial de víctimas mortales, lesiones y enfermedades entre los mineros demuestra que, en la mayoría de ellos, la minería sigue siendo el trabajo más peligroso en relación con el número total de trabajadores dedicados a esta actividad. resources in the best way.

An element to highlight is that the mining projects have unleashed various social and environmental conflicts, such as the concessions for exploration and exploitation to large national and international consortiums, characterized by extractive and degradative processes of the territories, of social exclusion (Gudynas, 2013, Valladares, 2018). In the case of Sombrerete, conflicts have not been reported among the actors involved in the process of marble extraction and commercialization. The fact that it is a mining of social type has exercised certain control on the appropriation of the resources and their conservation.

The volume of marble sales is an important indicator of the capacity for production and access to the market, which makes it possible for producers to plan the production, as well as to establish commitments to capitalize the company and obtain loans for the purchase of machinery and equipment. Table 8 shows a clear trend in relation to the cooperatives with higher organizational level being those that have higher volumes of marble sales.

At first sight it can be unnoticed, although the production units interviewed in the 3 cooperatives produce $7475 \mathrm{t}$ of white and grey marble monthly, which represent 750 to 800 trips to the transforming plants and, significantly, $250 \mathrm{t} /$ day, which is important in the generation of employment compared to large extractive mining. In addition, it should be highlighted that, according to Jennings (2012), despite important efforts carried out in many countries, the global rate of mortal victims, lesions and diseases among miners proves that, in most of them, mining continues to be the most dangerous job in relation to the total number of workers devoted to this activity. 
Cuadro 8. Promedio del volumen de venta mensual de mármol blanco y gris de las unidades de producción* entrevistadas por cooperativa.

Table 8. Average of the monthly sales volume of white and grey marble of the production units* interviewed by cooperative.

\begin{tabular}{lcc}
\hline Cooperativa & $\begin{array}{c}\text { Mármol blanco } \\
\text { (toneladas) }\end{array}$ & $\begin{array}{c}\text { Mármol gris } \\
\text { (toneladas) }\end{array}$ \\
\hline Puerto La Peńa, S. C. de R. L. de C. V. & 344 & 444 \\
Semidesierto, S. C. de R. L. de C. V. & 1452 & 2200 \\
Soyatalito S. C. de R. L. de C. V. & 2770 & 264 \\
\hline
\end{tabular}

*Unidades de producción integradas en subgrupos de tres o cuatro socios o por productores individuales dentro de una cooperativa, las cuales aportan mármol para cumplir con los compromisos de entregas de la cooperativa. En el caso de la cooperativa Soyatalito S. C. de R. L. de C. V., esta funciona como unidad de producción colectiva, es decir que funciona como una cooperativa. * Production units integrated into subgroups of three or four members or by individual producers within a cooperative, which contribute marble to fulfill the commitments of deliveries from the cooperative. In the case of the cooperative Soyatalito S. C. de R. L. de C. V., it functions as a collective production unit, that is, it functions as a cooperative.

\section{Nivel organizativo de las cooperativas en los ingresos de las unidades de producción}

Los ingresos mensuales por ventas de mármol blanco y gris de los productores entrevistados arrojan un promedio de $\$ 114061.35$, con un mínimo de $\$ 12670.00$ y un máximo de $\$ 223256.00$. A partir de los datos recabados sobre costos de producción e ingresos por las ventas de mármol, se obtuvo una estimación de los ingresos mensuales netos. Se observa que las cooperativas con un grado de organización menor y medio, tienen un ingreso mensual neto similar entre ellas, e inferior a aquella que tiene un grado de organización mayor (Cuadro 9).

\section{Nivel organizativo de las cooperativas y el acceso a los apoyos institucionales}

El número de apoyos gestionados por las cooperativas es un indicador de la capacidad de la viabilidad para la renovación de la maquinaria y equipo, así como de la capacidad de mantener e incrementar los

\section{Organizational level of the cooperatives in the income of production units}

The monthly income from white and grey marble sales from the producers interviewed result in an average of $\$ 114061.35$, with a minimum of $\$ 12$ 670.00 and a maximum of $\$ 223256.00$. An estimate of the net monthly income was obtained based on the data gathered about production costs and income from marble sales. It is observed that the cooperatives with a lower and medium degree of organization have a similar net monthly income between them, and lower than those that have a greater degree of organization (Table 9).

\section{Organizational level of cooperatives and access to institutional backing}

The number of supports negotiated by the cooperatives is an indicator of the ability of the variable to renovate the machinery and equipment, as well as the ability to maintain and increase the

Cuadro 9. Promedio de los ingresos netos mensuales de las unidades de producción entrevistadas por cooperativa.

Table 9. Average of monthly net income of the production units interviewed by cooperative.

\begin{tabular}{ccc}
\hline Cooperativa & *Nivel organizativo & Promedio de ingresos netos $(\$)$ \\
\hline Puerto La Peńa, S. C. de R. L. de C. V. & Bajo & 14866.00 \\
Semidesierto, S. C. de R. L. de C. V. & Medio & 13796.00 \\
Soyatalito S. C. de R. L. de C. V. & Alto & 44768.96 \\
\hline
\end{tabular}

*El nivel organizativo se determinó a partir del análisis de los aspectos de organización interna y clima organizacional de cada cooperativa. * *The organizational level was determined from the analysis of the internal organization aspects and organizational climate of each cooperative. 
niveles de producción. Cabe redundar que, si no se tiene acceso a apoyos, las cooperativas no podrán acceder a nuevos mercados, estancándose la capacidad de crecimiento y desarrollo local. La tendencia que sugieren los datos es que a nivel organizativo medio $\mathrm{y}$ alto se tiene, mayor capacidad de gestionar apoyos financieros (Cuadro 10).

Un indicador importante de la capacidad de gestión es el conocimiento de dependencias gubernamentales en las cuales se gestionan apoyos para el financiamiento de las actividades productivas. Los datos recabados indican que los productores entrevistados de la Cooperativa Puerto La Peña, S. C. de R. L. de C. V. no tienen información sobre a cuáles dependencias acudir; mientras que las dos cooperativas con mayor nivel organizativo declararon conocer dependencias de gobierno, bancos y microfinancieras.

\section{Impacto de la actividad de extracción de mármol en la economía familiar}

La opinión de los productores sobre el impacto de la actividad productiva en diferentes aspectos del bienestar familiar es un aspecto importante para evaluar si los ingresos que se obtienen están siendo suficientes. Las respuestas aportadas por los productores indican que la producción de mármol ha impactado positivamente en el bienestar familiar. La tendencia que muestran los datos es que un alto porcentaje afirma que las condiciones en el bienestar familiar han mejorado (Cuadro 11).

La actividad de extracción de mármol en la Comunidad se ha posicionado como una de las más importantes, en particular por el número de empleos y los ingresos que genera. De lo anterior se explica el alto impacto que ha tenido esta actividad productiva en los diferentes aspectos del bienestar familiar analizados. $\mathrm{Al}$ respecto, $75 \%$ de los productores entrevistados production levels. It should be mentioned that if they do not have access to supports, the cooperatives will not be able to gain access to new markets, making the ability for growth and local development stagnant. The trend that the data suggests is that at the medium and high organizational level there is greater ability to negotiate financial supports (Table 10).

An important indicator of the ability to negotiate is the knowledge of government agencies where supports are negotiated to finance the productive activities. The data gathered indicate that the producers interviewed from Cooperativa Puerto La Peña, S. C. de R. L. de C. V., do not have information about which agencies to go to, while the two cooperatives with higher organizational level declared knowing government agencies, banks and micro-financing.

\section{Impact of the marble extraction activity in the family economy}

The opinion of the producers about the impact of the productive activity in different aspects of family welfare is an important aspect to evaluate whether the income obtained is enough. The responses contributed by the producers indicate that marble production has impacted positively in family welfare. The trend that the data show is that a high percentage states that the conditions of family welfare have improved (Table 11).

The marble extraction activity in the community has been positioned as one of the most important, particularly by the number of jobs and the income that it generates. Based on this, the high impact that this productive activity has had on the different aspects of family welfare analyzed is explained. In this regard, $75 \%$ of the producers interviewed declared that the productive activity represents for them significantly

Cuadro 10. Número de apoyos financieros recibidos en los socios de las cooperativas en los últimos 5 años.

Table 10. Number of financial supports received by members of cooperatives in the last 5 years.

\begin{tabular}{|c|c|c|c|c|}
\hline Cooperativa & $\begin{array}{c}\text { Nivel } \\
\text { organizativo }\end{array}$ & $\begin{array}{c}\text { Núm. de Apoyos } \\
\text { recibidos }\end{array}$ & $\begin{array}{c}\text { Fuente o institución } \\
\text { que financió }\end{array}$ & $\begin{array}{c}\text { Monto total de los } \\
\text { apoyos }(\$)\end{array}$ \\
\hline Puerto La Peña, S. C. de R. L. de C. V. & Bajo & 0 & --.-- & ---- \\
\hline Semidesierto, S. C. de R. L. de C. V. & Medio & 4 & $\begin{array}{l}\text { Apoyo federal y empresa } \\
\text { compradora }\end{array}$ & 1728000 \\
\hline Soyatalito S. C. de R. L. de C. V. & Alto & 2 & Empresa compradora & 1420000 \\
\hline
\end{tabular}


Cuadro 11. Opinión de los productores sobre el impacto de los ingresos por la venta de mármol en aspectos del bienestar familiar. Table 11. Opinion of the producers about the impact of the income from the marble sale in aspects of family welfare.

\begin{tabular}{|c|c|c|c|c|c|c|c|c|}
\hline \multirow{3}{*}{ Aspecto } & \multicolumn{6}{|c|}{ Opinión de productores } & \multirow{2}{*}{\multicolumn{2}{|c|}{ Total }} \\
\hline & \multicolumn{2}{|c|}{ Ha mejorado } & \multicolumn{2}{|c|}{ Sigue igual } & \multicolumn{2}{|c|}{ Ha empeorado } & & \\
\hline & Frec. & $\%$ & Frec. & $\%$ & Frec. & $\%$ & Frec. & $\%$ \\
\hline Alimentación & 5 & 62.5 & 3 & 37.5 & 0 & 0.00 & 8 & 100 \\
\hline Educación & 6 & 75.0 & 2 & 25.0 & 0 & 0.00 & 8 & 100 \\
\hline Salud & 5 & 62.5 & 2 & 25.0 & 1 & 12.5 & 8 & 100 \\
\hline Vestido y calzado & 5 & 62.5 & 3 & 37.5 & 0 & 0.00 & 8 & 100 \\
\hline Actividades de recreación & 5 & 62.5 & 3 & 37.5 & 0 & 0.00 & 8 & 100 \\
\hline
\end{tabular}

declararon que la actividad productiva representa para ellos sensiblemente $100 \%$ de los ingresos para el sustento familiar, $25 \%$ de los entrevistados manifestaron que representa $90 \%$. De los productores entrevistados $50 \%$ manifestó que se dedican exclusivamente a la producción de mármol, $25 \%$ declaró practicar además la agricultura de autoconsumo y $12.5 \%$ afirmó dedicarse además a trabajar en la construcción.

\section{CONCLUSIONES}

La minería social que ilustra esta investigación, no obstante las debilidades organizativas observadas, es una alternativa frente a los procesos dominantes recientes de la minería en México, la cual bajo su modelo extractivo dominado por empresas transnacionales, genera importantes impactos ecológicos, económicos y sociales, en particular de derechos humanos. La minería social para el aprovechamiento de los recursos comunitarios y en este caso para el mármol, se ha posicionado como una de las actividades económicas más importantes en la comunidad, respecto al aprovechamiento colectivamente ordenado del recurso, la generación y mantenimiento de empleos al interior y al exterior de la comunidad; así como sus alcances en la mejora del bienestar familiar.

La lógica de gestión y aprovechamiento colectivo del recurso, impacta favorablemente en el arraigo de los productores de mármol y sus familias a la comunidad, disminuyendo la emigración y contribuyendo al fortalecimiento de la cohesión comunitaria, mediante modalidades de organización autogestiva para la extracción de mármol como recurso de propiedad colectiva.

La estructura organizativa para la producción se mantiene con instituciones comunitarias creadas por la misma comunidad para mantener el estatus del mármol como recurso colectivo. La extracción
$100 \%$ of the income for family sustenance, $25 \%$ of the interview respondents manifested that it represents $90 \%$. Of the producers interviewed, 50\% manifested that they are devoted exclusively to marble production, $25 \%$ declared practicing it in addition agriculture for auto-consumption, and $12.5 \%$ stated they are also devoted to construction work.

\section{CONCLUSIONS}

The social mining illustrated by this study, despite the organizational weaknesses observed, is an alternative in face of the recent dominant processes of mining in Mexico, which under its extractive model dominated by transnational companies generates important ecological, economic and social impacts, particularly on human rights. Social mining for the exploitation of community resources and in this case for marble, has been positioned as one of the most important economic activities in the community, compared to the collectively ordered use of the resource, the generation and maintenance of jobs inside and outside the community, as well as its reaches in the improvement of family welfare.

The logic of management and collective exploitation of the resource favorably impacts the rootedness of the marble producers and their families to the community, decreasing migration and contributing to strengthening the community cohesion, through self-management organization modalities for marble extraction as a resource of collective property.

The organizational structure for the production is maintained with community institutions created by the community itself to maintain the status of marble as collective resource. Marble extraction in the community contributes to family welfare due to income from sales; however, it has not developed 
de mármol en la comunidad contribuye al bienestar familiar por los ingresos por ventas, sin embargo, no ha desarrollado todo su potencial debido a su dependencia del mercado, que establece bajos precios del producto, combinados con crecientes y altos costos de producción. La problemática detectada coloca la insuficiente organización interna y al mercado como principales factores limitantes del desarrollo de la actividad productiva y el bienestar. La ineficiencia organizativa frente a las empresas compradoras y la consecuente incapacidad de negociar mejores precios del mármol, obstaculizan la modernización del sistema de extracción y limita las opciones de las cooperativas para buscar otros mercados.

Los procesos en curso evidencian la necesidad y conveniencia de talleres de educación y capacitación para la integración cooperativa, que contribuyan a consolidar las organizaciones cooperativas en sus valores y principios cooperativos, como sustento para su funcionamiento colectivo y sus planes estratégicos de desarrollo. Así como para su integración en una opción de unión de cooperativas marmoleras, como ejemplo local para atraer el interés público y privado con el objetivo de incursionar socialmente en encadenamientos de valor agregado, con interés en el mercado regional y nacional.

\section{LITERATURA CITADA}

Caddy, E. 2006. Las dimensiones sociopolíticas de la tenencia de la propiedad común indígena en el sur de Belice. In: El manejo de los recursos de uso común, derechos indígenas, desarrollo económico e identidad. Consejo Civil Mexicano para la Silvicultura Sostenible, Fundación Ford, Instituto Nacional de Ecología. México. 78 p

Cámara de Diputados del H. Congreso de la Unión. 2014. Reglamento de la ley minera. Diario Oficial de la Federación (31 de octubre de 2014). México.

Cámara de Diputados H. Congreso de la Unión. 2012. Ley Agraria. Diario Oficial de la Federación (11 de agosto de 2014). México.

Carretero, Anselmo, Valenciano Jaime de Pablo, y Velasco Juan. 2018. Recursos endógenos mineros y desarrollo territorial. El caso de la comarca del Mármol (Almería, España). Revista de Estudios Regionales No 111, I.S.S.N.: 0213-7585, pp: 51-75.

CIDVT (Comité Ixtepecano en Defensa de la Vida y el Territorio). 2016. Manual comunitario de defensa contra la minería a cielo abierto. BIBANI, A. C.-REMA. Consultado 6 noviembre. 2016. Link:http://www.noalaminaixtepec.org/ wp-content/uploads/2016/04/ MANUALMINAIXTEPECINTERNET12032016JUJUJU.pdf.

CONAPO (Consejo Nacional de Población). 2012. Índice de marginación por localidad 2010. México. Consultado el to its whole potential because it depends on the market, which establishes low prices of the product, combined with growing and high production costs. The problem detected places insufficient internal organization and the market as principal limiting factors for the development of the productive activity and welfare. The organizational inefficiency in face of purchasing companies and the consequent inability to negotiate better marble prices obstructs the modernization of the extraction system and limits the options of cooperatives to seek other markets.

The processes at place evidence the need and convenience of workshops on education and training for cooperative integration, which would contribute to consolidating cooperative organizations in their cooperative values and principles, as sustenance for their collective functioning and their strategic development plans. At the same time for their integration in an option of a union of marble cooperatives, as a local example to attract the public and private interest with the objective of making a social incursion into added value chains with interest in the regional and national market.

- End of the English version-

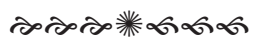

07 de noviembre de 2016. Link: http://www.conapo.gob.

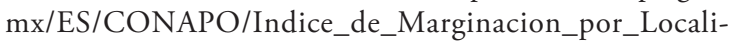
dad_2010.

Davison, Mazabel. 2007. Apuntes sobre organización social y riego en México. Revista de antropología experimental. Núm. 7. España. pp: 96-106.

Dirección General de Minas. 2012. Estudio de la cadena productiva del mármol. Secretaría de Economía. Consultado el 07 de noviembre de 2016. Link: http://www.economia.gob. $\mathrm{mx} /$ files/comunidad_negocios/industria_comercio/informacionSectorial/minero/cp_marmol_1013.pd. 35 p.

Feeny, David, Fikret Berkes, Bonnie J. McCay, and James M. Acheson. 1990. The tragedy of the commons: Twenty-Two years later. Human Ecology. Vol. 18. No. 1. (Consultado el 22 de noviembre de 2015). Link: https://www.researchgate. net/publication/226432105_The_Tragedy_of_the_Commons_Twenty-Two_Years_Later. pp: 1-19.

FONAES (Fondo Nacional de Apoyo a Empresas Sociales). 1998. Minería social, opción para la reconversión productiva del campo. México. 46. p.

Gudynas, Eduardo. 2013. Conflictos y extractivismos: conceptos, contenidos y dinámicas. DECURSOS Revista en Ciencias Sociales Año XV, Número 27-28, diciembre 2013.

Helfrich, S. 2008. Commons: ámbitos o bienes comunes, procomún o "lo nuestro". Las complejidades de la traducción de un concepto. In: Helfrich, Silke. (comp). Genes bytes y emi- 
siones: bienes comunes y ciudadanía. Fundación Heinrich Böll, Oficina Regional para Centroamérica, México y Cuba. México. pp: 42-48.

Hernández Roberto, Carlos Fernández, y María del Pilar Baptista. 2010. Metodología de la investigación. McGRAW-Hill. $613 \mathrm{p}$.

INEGI (Instituto Nacional de Estadística y Geografía). 1991. Querétaro. Datos por ejido y comunidad agraria. XI Censo General de Población y Vivienda, 1991. 64 p.

INEGI (Instituto Nacional de Estadística y Geografía). 2015. Anuario estadístico y geográfico de Querétaro. México. 418 p.

INEGI (Instituto Nacional de Estadística y Geografía). 2010a. Compendio de información geográfica municipal de los Estados Unidos Mexicanos, Cadereyta de Montes, Querétaro. México. Consultado el 7 de noviembre de 2016. Link: http://www.inegi.org.mx/geo/contenidos/topografia/compendio.aspx.

INEGI (Instituto Nacional de Estadística y Geografía). 2010b. Censo de población y vivienda. México. Consultado el 07 de noviembre de 2016. Link: http://www.inegi.org.mx/sistemas/consulta_resultados/iter2010.aspx?c=27329\&s=est.

ITAM (Instituto Tecnológico Autónomo de México)-Centro de Estudios de Competitividad. 2004. El Sector Minero en México: Diagnóstico, Prospectiva y Estrategia. México.

Jennings N. Visión general de la minería. In: Minas y canteras. Industrias basadas en recursos naturales. Directores del capitulo: J. Armstrong y Raji Menon. $N^{\circ} 74$. Enciclopedia de Salud y Seguridad en el Trabajo.

MEA (Millennium Ecosystem Assessment). 2005. Ecosystems and Human Well-being: Synthesis. Island Press, Washington, DC. 137 p.

Mendoza, Mirza, Luis Enrrique Ferro, y Eduardo Solorio. 2006. Otomíes del semidesierto queretano. $47 \mathrm{p}$.
Ostrom, Elinor. 1990. Governing the commons. The evolution of institutions for collective action. Cambridge University Press. 280 p.

RAN (Registro Agrario Nacional). 2016a. Datos abiertos. Consultado el 04 de noviembre de 2016. Link: http://datos.ran. gob.mx/conjuntoDatosPublico.php

RAN (Registro Agrario Nacional). 2016b. Padrón e historia de núcleos agrarios-datos generales. México. Consultado el 07 de noviembre de 2016. Link: http://phina.ran.gob.mx/phina2/Sessiones.

SAGARPA (Secretaría de agricultura, Ganadería y Desarrollo Rural). 2000. Guía de desarrollo rural sustentable, participativa e incluyente. Fasc.5. Minería y pesca. México. 35 p.

SAGARPA (Secretaría de agricultura, Ganadería y Desarrollo Rural). 2015. Componente Minería Social. Consultado el 08 de noviembre de 2016. Link: http://www.sagarpa.gob. $\mathrm{mx} /$ Delegaciones/tlaxcala/Documents/C-2015/Convocatorias/Convocatoria\%20MINERIA\%20SOCIAL.pdf.

Silva, L. J., Juárez L. G., Acosta P. R., y Orosco F. S. 2012. Educación ambiental en el aprovechamiento del mármol en San Pedro y San Pablo, Teposcolula, Oaxaca. Ra Ximhai, 8(2): 229-235. Edición Especial: Contaminación y Medio Ambiente.

Valladares, Laura. 2018. El asedio a las autonomías indígenas por el modelo minero extractivo en México. Iztapalapa Revista de Ciencias Sociales y Humanidades núm. 85 año, 39 juliodiciembre.

Valladares, Laura. 2017. El despojo de los territorios indígenas y las resistencias al extractivismo minero en México. e-cadernos ces [En línea], 28, consultado el 30 de septiembre 2018. URL: http://journals.openedition.org/eces/2291; DOI : $10.4000 /$ eces. 2291.

Wade, Robert. 1994. Village republic, Economic conditions for collective action in south India. Institute for Contemporary Studies. San Francisco, California. 238 p. 